\title{
AUSTRALIAN
}

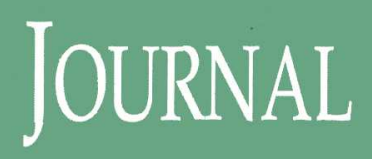

OF

\section{GUIDANCE AND}

CounselLING

\author{
VOLUME 5 NUMBER 1
}

NOVEMBER 1995

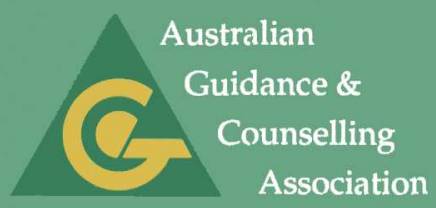




\section{Australian Journal of Guidance \& Counselling}

\section{Editor}

John Carroll, Director of Career Education, John Paul College, Queensland

\section{Editorial Panel}

Gabrielle Elich, Guidance Officer, Queensland

Greg Field, Senior Guidance Officer, New South Wales

Robynne Moore, Guidance Officer, Victoria

\section{Australian Guidance \& Counselling Association Inc 1995/96}

\section{Executive Members}

President

Secretary

Treasurer

Membership Secretary

Newsletter Editor

Immediate Past President

Journal Editor

\section{State Representatives}

New South Wales

Victoria

Queensland

South Australia

Tasmania

Western Australia

Northern Territory

Australian Capital Territory
Jan Wilson

Lorraine Murphy

Royce Herbert

Kate Prescott

Robyn Gillies

Kate Prescott

Ivan Watson

The Australian Journal of Guidance and Counselling presents articles of relevance to all areas of guidance and counselling. Papers may address theoretical, practical or training issues, and may focus on educational or psychological topics.

Subscriptions: The Journal is published annually. Subscription rates are AGCA members - $\$ 10$ (included in annual membership fee); Individuals (non-AGCA members) - \$12; Institutions - \$15.

Requests for subscriptions should be sent to:

Australian Guidance \& Counselling Association Inc

30 Frank Street

Vermont Vic 3133

Tel.: (03) 95603327 Fax: (03) 98726249 


\section{AUSTRALIAN JOURNAL \\ $\mathrm{OF}$ \\ GUIDANCE\&COUNSELLING}

Volume 5 Number 1 November 1995

\section{Contents}

iii Editorial

\section{Professional Issues}

1 Beyond phrenology: The beginnings of vocational guidance in Queensland through 'Sagax, Capax and Efficax'

Denis Arthy

13 An investigation of guidance officer selection criteria Sam Beavers

21 An investigation of perceptions of guidance officers and secondary principals as to present and preferred level of guidance officer practice in secondary schools Kym Dickinson

31 Employers' and senior psychologists' expectations of the educational coverage and skills of four-year educated psychologists

John Franklin, Joan Gissing and Helen Holubinskyj

41 The limitations of counsellors' knowledge highlighted by examining the concept 'authenticity'

Raj Sanggaran

49 Inaugural Constance Davey memorial lecture

Rosalyn Shute

\section{Research papers}

59 Cognitive behaviour therapy vs rational emotive education: Impact on children's self-talk, self-esteem and irrational beliefs

Paul C. Burnett 
67 Behavioural interactions of children in classroom-based work groups

Robyn Gillies and Adrian Ashman

\section{Field reports}

$81 \quad$ Suicide prevention and schools

Dr Chris Cantor

87 Teaching decision making in schools. How well does it work?

Ailsa Drent and Erica Frydenberg

99 Factors affecting the implementation of the NSW

Department of School Education child protection curriculum

Daphne Hewson, Anne Nielsen and Caroline Powell

111 Selective mutism: A school-based intervention

Nonie Kirkby

119 Off-campus education centres: An evaluation and suggestions for the future

Bruce Muirhead

\section{Reviews}

147 Cultures of crime and violence - the Australian experience

Kate Prescott

147 Bill Rogers Managing Behaviour Videos:

Prevention; Repair and rebuild

Katrina Spencer

148 Vocational Interest Survey for Australia (VISA)

Ros Lim

149 Developmental disabilities: Psychosocial aspects

Philip Doyle

150 Supervision: Exploring the effective components

Marie Thompson

ISSN $1037-2911$ 